\title{
Electrostatic Energy Storage
}

\author{
R. L. Macklin
}

\section{OAK RIDGE NATIONAL LABORATORY}




\section{DISCLAIMER}

This report was prepared as an account of work sponsored by an agency of the United States Government. Neither the United States Government nor any agency Thereof, nor any of their employees, makes any warranty, express or implied, or assumes any legal liability or responsibility for the accuracy, completeness, or usefulness of any information, apparatus, product, or process disclosed, or represents that its use would not infringe privately owned rights. Reference herein to any specific commercial product, process, or service by trade name, trademark, manufacturer, or otherwise does not necessarily constitute or imply its endorsement, recommendation, or favoring by the United States Government or any agency thereof. The views and opinions of authors expressed herein do not necessarily state or reflect those of the United States Government or any agency thereof. 


\section{DISCLAIMER}

Portions of this document may be illegible in electronic image products. Images are produced from the best available original document. 
Printed in the United States of America. Available from

National Technical Information Service

U.S. Department of Commerce

5285 Port Royal Road, Springfield, Virginia 22161

Price: Printed Copy $\$ 3.50$; Microfiche $\$ 2.25$

This report was prepared as an account of work sponsored by the United States Government. Neither the United States nor the Energy Research and Development Administration/United States Nuclear Regulatory Commission, nor any of their employees, nor any of their contractors, subcontractors, or their employees, makes any warranty, express or implied, or assumes any legal liability or responsibility for the accuracy, completeness or usefulness of any information, apparatus, product or process disclosed, or represents that its use would not infringe privately owned rights. 
ORNL/TM-5529

Contract No. W-7405-eng-26

Physics Division

- Electrostatic Energy Storage

R. L. Macklin

SEPTEMBER 1976

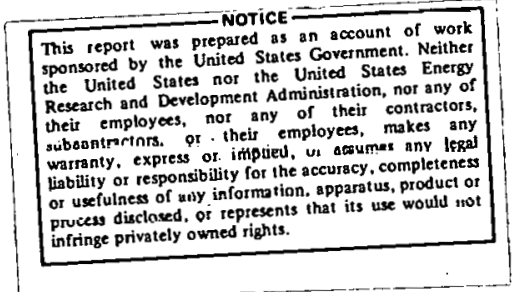

NOTICE This document contains information of a preliminary nature and was prepared primarily for internal use at the Oak Ridge National Laboratury. Il is subject to rovision or correction and therefore does not represent a final report.

\author{
OAK RIDGE NATIONAL LABORATORY \\ Oak Ridge, Tennessee 37830 \\ operated by \\ UNION CARBIDE C.ORPORATION \\ for the \\ ENERGY RESEARCH AND DEVELOPMENT ADMINISTRATION
}

OT $W-7405-E N G-26$ 


\section{Electrostatic Energy Storage*}

R. L. Macklin

Physics Division

Oak Ridge National Laboratory, Oak Ridge, Tennessee 37830

\section{Abstract}

The advantages of capacitor storage of energy, particularly for automotive use are reviewed and compared with alternatives. A few suggestions for research possibilities for possibly suitable organic dielectrics are given.

\section{Introduction}

With shortages of oil and gasoline clearly facing the world, it is time to consider all other possibilities for storing energy effectively. Leading possibilities for automotive use include advanced electric batteries $^{1}$ and specially designed flywheels. ${ }^{2}$ Some interest is also shown in superconducting magnet storage although the cryogenic problem seems formidable for automotive use.

The object of this paper is to urge the reconsideration of electrostatic or capacitor storage for such an application. First, note that there are several practical advantages to such a system if a suitable organic chemical polymer can be developed as the dielectric.

The efficiency in converting the stored electric energy to mechanical energy to turn wheels can confidently be expected to be very high; close to $90 \%$. This means that substantially less energy need be stored in a vehicle (about 1/7) for equal range, speed, acceleration, etc., compared to a gasoline burning system. There is no exhaust to pollute the air and *Research sponsored by the U. S. Energy Research and Development Administration under contract with Union Carbide Corporation. 
even thermal pollution by wasted heat is reduced by a factor of 9 or so at the vehicle. Of course, heat must be carefully dissipated back at the power house that generates the electricity but an overall gain of a factor of nearly 3 is still to be expected. The real but modest efficiency gains from regenerative braking have been emphasized previously vis a vis the gasoline driven system. ${ }^{2}$

The storage system can be expected to operate at a normal range of temperature though some form of protection against fire and collision would be needed. Operation from sea level to mountain altitudes should present no problems as any air pressure sensitive components coutd be hermetically sealed at the factory.

Recharging can be done rapidly and efficiently compared with conventional battery charging. A few minutes should suffice at a service station equipped with suitable rectifying equipment and industrial capacity electric supply lines. Alternatively, residential electric supply is generally adequate for overnight charging at home (at off peak electric rates too!)

There should be no need for raw materials in short supply unless the organic dielectric were based on a rare element as a major constituent. The solid state switches for control and series-parallel interconnection of individual conicitor "sells" require silicon, a very abundant element. The organic material for the dielectric should be comparable in amount to the synthetic rubber currently used in tires. Aluminum could be used for wiring if a shortage of copper became critical. Only in the newest magnetic materials for wheel motors is a possible shortage of raw materials anticipated, and there, of course, the older materials based on iron and the iron group elements would be satisfactory substitutes. 
Capital costs for the dielectric should be comparable to those already known for specialized plastic sheet. ${ }^{3}$ The paucity of moving parts should provide a significant improvement in both capital and maintenance costs. For instance, the relative economic advantages of $D C$ vs $A C$ drive motors would no longer be clear and the choice might lead to even fewer parts such as brushes and commutators to wear out.

\section{Material Basis of Energy Storage Systems}

The combustion engine systems (gasoline, Diesel fuel) exploit the availability of free air to achieve a high capacity for chemical energy storage; $\sim 4 \times 10^{7}$. joules $/ \mathrm{kg}^{-1}$. Conversion efficiency from thermal energy to automotive propulsion reduces this nearly to $4 \times 10^{6}$ joules $/ \mathrm{kg}^{-1}$. On a molecular basis, carbon to hydrogen (and carbon to carbon) chemical bonds are exchanged through combustion for the stronger carbon-oxygen and hydrogen-oxygen bonds, freeing the difference in energy as heat.

The lead storage battery exploits the overall reaction $\mathrm{Pb}+\mathrm{PbO}_{2} \rightarrow$ $\mathrm{PbO}+\mathrm{PbO}$, effected through ion (and electron!) migration, to produce electric power directly. The stored energy is only about $4.4 \times 10^{4}$ joules/ $\mathrm{kg}^{-1}$ but there is no (further) thermal cycle inefficiency involved in its use. It is notable however that even with its drawbacks the lead-acid storage battery is being revived to operate cars for city driving, and battery operated delivery trucks have had a long history.

Advanced batteries such as the 1 ithium-sulfur ce $11^{1}$ promise a gain of several fold in energy storage density, but share some of the battery drawbacks such as slow charging rate and will add new ones, especially the need for high temperature operation. 
A great deal of work has gone into the development of fuel cells but automotive application seems to have been abandoned. Through the use of free air, the potential for energy storage of such systems rivalled the gasoline-combustion engine system. Technical problems presumably have proved intractable.

Another recent development has turned to mechanical energy storage in flywheels. ${ }^{2}$ By the use of ultra strong fiber composites and optimized structural design, capacities, comparable to gasoline combustion in useful automotive energy are expected.

One of the possibilities considered in superconducting magnet research is electric energy storage. At temperatures below the boiling point of hydrogen (near $20^{\circ} \mathrm{K}$ ) many materials have been found to support persistent ring currents. The loss of energy in continuously refrigerating the material far outweighs inherent ohmic losses due to imperfections. The limits of magnetic field that can be sustained have risen substantially in the past decade, particularly for niobium based composites. For practical energy storage densities one will again be pressing the strength of materials of construction as in a flywhee? storage.

All of these approaches can be viewed in a unified way in terms of ionic, molecular and intermolecular bond strengths or bond energies. These are typically a few electron volts per bond. Examples are Li-Li $(1.0 \mathrm{eV}), \mathrm{Li}-\mathrm{Cl}(4.9 \mathrm{eV}), \mathrm{C}-\mathrm{H}(3.5 \mathrm{eV}), \mathrm{C}-\mathrm{C}(6.25 \mathrm{eV}), \mathrm{C}-\mathrm{N}(7.55 \mathrm{eV})$, C-0 $(11.1 \mathrm{eV}), \mathrm{C}-\mathrm{F}(4.6 \mathrm{eV}), \mathrm{Si}-0(8.3 \mathrm{eV}), \mathrm{Pb}-\mathrm{Pb}(1.0 \mathrm{eV}), \mathrm{Pb}-0(4.3$ eV). In terms of power storage density, other factors such as overall density and molecular weight per bond will also be important. In general, though, all the approaches considered earlier will experience similar 
limits in storage capacity. Factors of a more practical nature will then determine the best system for a particular use. These include materials availability, manufacturing techniques, operating conditions such as temperature range and speed of recharge, etc.

Many years ago Locke ${ }^{4}$ suggested that new dielectrics might provide the best hope for the ultimate solution to the electric energy storage problem. The stored energy in a flat sheet capacitor is given as

$$
E=C V^{2} / 2
$$

with units: joules or watt seconds $(E)$, farads $(C)$, and volts (V). In practice thin sheets of dielectric material, coated with thin metal electrodes to apply the voltage, are rolled up and put into cylindrical tubes. Thus it is convenient to express the energy storage in the dielectric "meat" of such a sandwich on a volume basis, recognizing that there will be some additional volume required for the thin electrodes and an outer casing

$$
D=0.4427 \times 10^{6} \mathrm{Ka} \mathrm{a}^{2}
$$

with $D$ in kilojoules per cubic meter and a in volts per Angstrom. $K$ is the low frequency (static) dielectric "constant" measured as the ratio of the capacitance using a particular material (at a particular temperature) to that of a vacuum occupying the same space in a test condenser. Many commonly used condenser dielectrics have dielectric constants below ten, corresponding to strong ionic or more often to non-polar interatomic bonds. A class of metal titanate ceramics have shown dielectric constants up to 12000. Such behavior is correlated with weakening some titaniumoxygen bonds (over a fraction of an Angstrom), in this case by maximum thermal stretching of the Perovskite lattice structure. 
The dielectric "strength" a is sharply reduced by impurities and imperfections in a material and thus rather $i 11$ defined. At a slightly higher voltage gradient "breakdown" occurs, resembling miniature lightning whereby conducting pathways through the material are formed. Presumably the process must start by breaking at least one bound electron loose or by breaking an ionic bond. To avoid this the bonding must remain uniformly strong at atomic dimensions ( 2 Angstrom). In paper thin sheets, appropriate to capacitor construction, high purity can be achieved in mica and organic polymers. Adhesive electric insulating tape can be guaranteed for use at 1000 volts per $2.54 \times 10^{-5} \mathrm{~m}(\mathrm{mi1})$, and mica approaches 225,000 volts per millimeter $(a=0.0225)$. Other organic polymers (polyamides) rate as well as mica in dielectric strength $(a=$ 0.028 ) and probably exceed it in still thinner sheets. Using the energy storage formula for mica with a dielectric constant of $\sim 5$ to 7 we might expect a storage capacity of $1000-1500 \mathrm{kj} \mathrm{m}^{-3}$ of mica. Commercial energy storage capacitors were found listed up to $600 \mathrm{kj} \mathrm{m}^{-3}$, based on a waxed paper dielectric, ${ }^{5}$ so this level of energy density is close to commercial practice. We can expect that no materials could appreciably exceed a dielectric strength of one volt per Angstrom as bond strengths and lengths are of this order. Extremely thin layers formed by oxidation of silicon and aluminum surfaces may approach this limit.

If we take the lead-acid storage battery at $44,000 \mathrm{j} \mathrm{kg}^{-1}$ as an aiming point, we would need to develop a material with the dielectric strength of the best plastic, incorporating enough polarizable sites to raise the dielectric constant well above 130 . This is a reasonable aim for economic impact as the lead-acid battery already provides marginal 
performance for electric cars and trucks. At the same time it is clearly unreasonable to hope for materials allowing a thousand times greater energy storage density, exceeding the heat from gasoline burned with free air.

Although many promising materials are beginning to be reported, perhaps I can add a few of my own speculations. First, simple dipolar molecules dispersed in an insulating liquid seems short of the mark. They could be largely aligned (polarized) by an applied field but the restoring force of thermal agitation would provide less than $1 / 40$ electron volt per dipole. Of course, if the dipole could be significantiy stretched without breakdown, that would be another matter. If the dipoles were several atoms long (like TTF-TCNQ) and the liquid could be polymerized to long chain molecules, the restoring force could be increased. In this technique, a thin polymer sheet ${ }^{3 b}$ is stretched in two directions during manufacture so the dipoles tend to be trapped with their axes within a few degrees of the plane of the sheet.

More sophisticated approaches envisage specially tailored organic molecules incorporating ionic bonds such as polyelectrolytes, metalorganics, ion exchange resins, etc. Flat molecules like the porphyrin rings in haemoglobin can bind polyvalent metals in the plane of the rings, leaving the perpendicular direction free. Layers of such substituents might provide the basis for a material of high dielectric constant in the one dimension.

\section{Conclusion}

A search for materials (particularly polymers) with high dielectric strength and static dielectric constant might lead to economically attractive electric storage systems, applicable to mobile as well as stationary installations. 


\section{References}

1. For instance Argonne National Laboratory is proceeding to an automotive test development with their lithium-sulfur storage battery. M. Warshay and L. 0. Wright in NASA TM X-3192 (February 1975) have emphasized the economic attractiveness of a pumped iron chloridetitanium chloride electrochemical storage system for power load leveling in electric utility systems.

2. R. F. Post and S. F. Post, Sci. Amer. 229, 17-23 (1973).

3. "Mylar", "Polarold", Pulyethyleme and Pulyvinyl Fluoride are examples of plastics produced in thin sheets.

4. E. L. Locke, "New Dielectrics" A.S.F. 72-86 ( (1955).

5. ELMAG Corporation $0.01 \mathrm{mfd}, 160 \mathrm{kv}$, Rapid Discharge Energy Storage Capacitor rated "10 joules per cubic inch". 
ORNL/TM-5529

INTERNAL DISTRIBUTION

1. H. W. Bertini

2. J.W. T. Dabbs

3. J. L. Fowler

4. J. Halperin

5. J. A. Harvey

6. R. W. Ingle

7. W. S. Lyon

8-17. R. L. Macklin

18. F. C. Maienschein

19. R. E. Minturn

20. G. L. Morgan

21-40. C. Oen

41. H. Postma
42. S. Raman

43. H. H. Ross

44. M. J. Saltmarsh

45. M. J. Skinner

46. G. G. Slaughter

47. P. H. Stelson

48. I. Thomas

49. A. Zucker

50-51. Central Research Library

52-53. Laboratory Records Dept.

54. Laboratory Records, ORNL-RC

55. ORNL Y-12 Technical Library

\section{EXTERNAL DISTRIBUTION}

56. G. L. Rogosa, Assistant Director for Nuclear Sciences, Division of Physical Research, J-309, U. S. Energy Research and Development Administration, Washington, D. C. 20545.

57. S. Whetstone, Division of Physical Research, U. S. Energy Research and Development Administration, Washington, D. C. 20545.

58. R. L. Hirsch, Ass istant Administrator for Solar, Geothermal and Advanced Energy Systems, U. S. Energy Research and Development Administration, Washington, D. C. 20545.

59. Research and Technical Support Division, ERDA-ORO.

60-86. Technical Information Center, Oak Ridge, Tennessee 37830. 